Journal of Teacher Education for Sustainability, vol. 23, no. 1, pp. 22-40, 2021

\title{
The IraunIK and IraunIR Questionnaires: Assessment of Transversal Competencies for Sustainability
}

\author{
Itziar Rekalde-Rodríguez, Pilar Gil-Molina and Esther Cruz-Iglesias \\ University of the Basque Country, Donostia-San Sebastián, Spain
}

\begin{abstract}
This article shows the design and validation of two questionnaires addressed to students and teachers. The aim is to find out their perception about the competencies and learning outcomes for sustainability that students develop through their participation in the international cross-border project of the Bordeaux-Euskampus "Ocean i3: Blue Skills for the Development of the Blue Economy in the Basque-Aquitaine Cross-Border Coast". The study population consisted of all the participants of the project: 37 students majoring in Biology, Law, Advertising, Business Administration and Management, Pedagogy, Criminology, Nursing, Engineering and Sports Sciences at the University of the Basque Country (UPV/EHU) and the University of Bordeaux (UBx), and 33 undergraduate and postgraduate lecturers from both universities. The article describes the procedure followed for their validity and reliability, and annexes both questionnaires. They may be transferable to other studies that share the same or similar objectives of this study.
\end{abstract}

Key words: higher education, learning environments, learning outcomes, sustainability, transversal competencies

\section{Introduction and Justification}

Ocean i3 is an inter-university (University of the Basque Country (UPV/EHU), Université de Bordeaux (UBx)) and international/cross-border (Basque Coast-New Aquitaine) project, in line with a positioning regarding the sustainability and exploitation of the oceans that pursues Sustainable Development Goals (SDGs) No. 14 (life below water), No. 5 (gender equality) and No. 6 (clean water and sanitation) of the 2030 Agenda for Sustainable Development adopted by the General Assembly of the United Nations (UN) in September 2015. Ocean i3 (Ikaskuntza/Ikerkuntza/IraunkortasunaLearning/Research/Sustainability) is being financed by the European Regional Development Fund (ERDF) through the third round of the Interreg V-A Spain, France, Andorra program (POCTEFA 2014-2020).

Students are offered the chance to carry out different types of task/activities (obligatory or voluntary internship, projects, graduate papers, etc.) aimed at a common mission, which focuses on the pollution of oceans by plastic. This is done using the approach 
known as Mission-Oriented Research and Innovation (Mazzucato, 2018; Sachs et al., 2019), which sets out to direct research, innovation and training at the global level in order to transform them into achievable, specific and measurable regional missions. It should also adhere to the Civic University model, with the aim of fostering the competitiveness of the universities taking part at the global level, as well as their commitment at the local level to this issue (Goddard et al., 2012).

Lecturers and students at both universities work within their own curriculum framework and within Ocean i3 to share, compare and enrich their work in an environment that is international, inter-cultural and inter-disciplinary, allowing for collaboration with social stakeholders and addressing real issues and challenges in the cross-border coastal region. This strengthens the regional development dimension (network of regional stakeholders and challenges) and fosters the development of students' competencies in terms of employability and sustainability, in this case in the sphere of the cross-border coastal blue economy. In this context, the community is seen as one that broadens its margins and projects itself outwards, seeking to form a broader community, in which specialists collaborate with their services to generate knowledge without being members of it. In short, their advice is enriching in that it provides specific knowledge or a multidisciplinary view of the matter in question (Lahneman, 2010; Ponsa, 2016).

In teaching terms, the project has been monitored by the Ikas Gura research group at the UPV/EHU (recognized by the Basque government as a level B consolidated research group, IT 1348-2019, using an action research model (Bradbury-Huang, 2010; McNiff \& Whitehead, 2011) to allow an action plan to be put in place concerning any issues that are problematic or needed by the community (planning, action, observation/reflection and replanning), involving the extended community to achieve the goal. It is also internal action research as the researchers are part of the community, i.e., although they have privileged information, they must work in a realistic, critical way that goes beyond their own subjectivity through the quality of data, understanding of the data, giving reasoned judgements and taking responsible actions (Coghlan, 2007).

At the beginning of academic year 2019/20, the project community suggested to the research group the need to explore the competencies students develop when they take part in this project on sustainability. The concern came from previous assessment reports and work carried out by internationally-recognized experts in academic year 2018/19, which made clear that Ocean i3 is a privileged space for learning (multilingual in Spanish, French, Basque and English as the lingua franca; trans-disciplinary, involving students and lecturers from different universities and different degrees and areas of knowledge; with a single objective or mission, i.e., to reduce plastic pollution of the oceans, the seas that we share, which bring us together and keep us alive; and committed to finding solutions to real, specific issues - social, economic and technological - raised by members of the community and likely to mobilize competencies that may be hard to develop in other curriculum areas). It should not be forgotten that, according to the World Economic Forum, $75 \%$ of the professions of the future are as yet unknown (Stefanova \& Leopold, 2018), and transversal competencies will be the most necessary ones in the 21st century (OECD, 2019).

The research team took up the challenge of constructing tools to identify the competencies and learning outcomes developed by students taking part in the Ocean i3 project and in other learning environments involving education for sustainability undertaken within the framework of the SDG in higher education. 


\section{Education for Sustainability in Higher Education Institutions}

Researching education for sustainability, it must be understood that the concept of sustainability goes beyond the concept of the environment, as it seeks not only environmental quality, but also quality in terms of fairness and social justice. From this point of view, the university can be seen as a potential driver of change in approaching sustainability, as its role focuses on training future professionals who will take decisions that will have a direct or indirect influence on their environment (Martínez et al., 2007).

The fact that, during their training, university students constantly reflect on sustainability can lead them to internalize ethical criteria for sustainable development, and include this as part of their professional competencies. As Rieckmann (2012) recalls, universities play an important role in shaping the future of global society in terms of sustainable development, as they generate new knowledge and contribute to the development of appropriate competencies, as well as raising awareness of sustainability. Education for Sustainable Development (ESD) at university is necessary to enhance individual capacity and commitment to building sustainable societies (Prabawani et al., 2020), and this calls for a training that forms a transversal part of the curriculum.

In 2015, the UN adopted the 2030 Agenda for Sustainable Development, in which it recognized that the greatest challenge in today's world would be the eradication of poverty, because without this there could not be sustainable development (UN, 2015). This agenda contains 17 objectives, known as Sustainable Development Goals (SDGs), aimed at the economic, social and environmental development of the planet. Several actions have been implemented since then. For example, the UNESCO Chair on Interplay of Tradition and Innovation in ESD initiated a targeted development of the Journal of Teacher Education for Sustainability and the Baltic and Black Sea Circle Consortium for educational research, which allowed for more effective implementation of the SDG set for teacher education and higher education after 2015. The philosophy of both actions is to reduce the current unsustainability of education in order to make it more visible (Salite et al., 2020). Furthermore, since its approval many universities have taken the 2030 Agenda on board and included its principles and values in their own goals, policies and activities. In fact, the agenda is an opportunity for universities to reassess the role of higher education institutions and shed light on the need to include certain values and practices in their mission. More and more experiences are emerging of universities undertaking transformation projects that go beyond the pedagogical focus to deal with holistic dynamics, in which the universities align themselves with the SDG as a related, complex whole (Leal Filho et al., 2018; Mawonde \& Togo, 2019; Mori, Fien, \& Horne, 2019; Paletta \& Bonoli, 2019). The literature reveals that the integration of the SDG in universities is a growing field of study; there is evidence of a percentage increase in documents published between 2013 and 2018 (Murillo-Vargas, González-Campo, \& Ico, 2020).

In the Spanish university context, CRUE, the Spanish university rectors' conference, sets the SDGs as one of their priorities and suggests Sustainable Development be considered as the core of its decisions and activities (CRUE, 2019). Moreover, the Strategic Plan for 2018-2021 and the 2030 Agenda for Sustainable Development at the University of the Basque Country (UPV/EHU) set out to contribute to sustainability (University of the Basque Country, 2018 \& 2019). This plan describes the contribution to 12 of the 17 SDGs, together with three sector-specific plans (Equality Campus, Inclusion Campus and Planet Campus), as well as the sustainable development indicator panel, which 
deals with technical aspects of monitoring the SDGs (Sáez de Cámara et al., 2021). Furthermore, in view of the idiosyncrasy and location of this university, where a minority ancestral language survives and is used, i.e., Basque coexists with other languages like Spanish and French, this considerable linguistic and cultural diversity is added to the 17 SDGs as a further goal, the 17+1 referring to the development of the Basque language and culture and multilingualism (University of the Basque Country, 2019).

\section{Key Competencies in Higher Education for Sustainability}

This drive for sustainable development in the European Higher Education Area, in which students' training is approached in terms of developing competencies, means the competencies for sustainability need to be defined.

Many universities have engaged in activities to put the ESD into practice by attempting to identify the competencies that are most important to sustainable development as a fundamental part of higher education oriented towards the future. Different approaches to selecting key competencies for sustainability have been developed, but there is no international agreement in the debate over which is the most important. Haan (2010) proposes a model for competencies in ESD that has been developed and disseminated in connection with two programs in the Federal Republic of Germany, planned to implement the EDS concept in schools throughout the country. Rieckmann (2011 \& 2012) wonders which individual key competencies are critical to understanding the central challenges faced by global society and help it develop towards a more sustainable future. The empirical design is based on a Delphi study, in which the key competencies for sustainability are defined by selected experts from Europe (Germany and Great Britain) and Latin America (Chile, Ecuador and Mexico). The results show that eleven key competencies crucial to sustainable development can be identified and the most important competencies are systematic, anticipatory and critical thought. In line with this finding, the abovementioned document by CRUE (2012) specifies four transversal competencies for sustainability: critical contextualization of knowledge by making connections between local and/or global social, economic and environmental issues, sustainable use of resources, participation in community processes to foster sustainability and application of ethical principles related to the values of sustainability in personal and professional behavior. On the basis of the key learning proposed by UNESCO and of the different classifications of competencies, Murga-Menoyo (2015) recreates a basic matrix of competencies for sustainability, stressing those of: critical analysis, systematic thought, collaborative decision-making and a sense of responsibility towards present and future generations. Furthermore, in the catalogue of transversal competencies used by the University of the Basque Country (UPV/EHU) (Uranga et al., 2019), and taking as a point of reference the classification of competencies in the Asia-Pacific project (Care \& Luo, 2016), the following are specified: autonomy and self-regulation, teamwork, critical thought, innovation and enterprise, professional responsibility and ethics, information management and digital citizenship, communication and multilingualism and social commitment. The last two of these refer to the use of verbal and non-verbal language from a gender perspective within an inclusive, multicultural and multilingual context; and social commitment is closely connected with the SDG, referring to dealing with empathy and responsibility with social, environmental and economic challenges at the local, national and global level, as well as the basic democratic values in today's society. 
Finally, it should not be forgotten that it is necessary to identify the learning outcomes to be assessed in relation to the said competencies (Rieckmann, 2011; Rieckmann, 2012), and as Barth et al. (2007) recall, the development and assessment of these take place in both formal and informal learning environments considered in this study.

\section{Methodology}

\section{Objectives}

The objectives set are the following:

- To design a questionnaire aimed at students (IraunIK) and lecturers (IraunIR) involved in sustainability environments to find out how they perceive the competencies and the learning outcomes involved;

- To study the validity of the content and the reliability of the IraunIK and IraunIR questionnaires in order to transfer the use of these questionnaires to other sustainability learning environments.

\section{Preparing and Validating the Questionnaires}

The questionnaires, “Students' Perception of the Development of Transversal Competencies for Sustainability (IraunIK)" and "Lecturers' Perception of the Development of Transversal Competencies for Sustainability among their Students (IraunIK)", are unpublished and were drawn up on the basis of reviewing other studies related to the object of the present research. The name IraunIK comes from the abbreviation of the concepts - in Basque - Iraunkortasuna (sustainability) and Ikasle (students), and IraunIR - from the concepts Iraunkortasuna (sustainability) and IRakasle (teachers).

\section{Process of Preparation}

The preparation of the IraunIK and IraunIR questionnaires involved the following phases:

Phase I. Bibliographical review: analysis of the literature on developing transversal competencies, competencies for sustainability and authentic learning environments for developing competencies. First draft of the questionnaires.

Phase II. Analysis and review of the draft IraunIK and IraunIR questionnaires and validation by the experts related to the object of study. Preliminary preparation (I) of the questionnaires in the four languages used in the project.

Phase III. Validation of the content of the questionnaires by experts. Analysis of the information gathered, restructuring of the questionnaires and preparation of the preliminary questionnaires (II).

Phase IV. Preliminary questionnaires (II) sent out to the whole population (students and lecturers) taking part in the project in academic year 2019/20.

Phase V. Analysis of data. Analysis of the reliability of the questionnaire.

Phase VI. Rewriting of the questionnaires in the light of the results obtained. Final preparation of the IraunIK and IraunIR questionnaires. 
In any process of preparation and validation of information gathering tools, the first step is to identify the overall aim and the dimensions this includes (Ruiz, 2014). In this case, the questions posed in the questionnaire refer to: 1) general details for contextualization, 2) tasks performed by students in the learning for sustainability environment, and 3) perception of how far these tasks enabled students to develop competencies and learning outcomes for sustainability. The questionnaire is made up of items in these sections: 1) general details for contextualization, and 2) competencies and learning outcomes for sustainability. Next, the items in each section were written. There are a total of 81 items in each questionnaire, divided into 2 sections plus subsections (see Table 1 ).

\section{Table 1}

Sections and Sub-sections of the IraunIK and IraunIR Questionnaires

\begin{tabular}{llc}
\hline \multicolumn{1}{c}{ Section } & \multicolumn{1}{c}{ Sub-section } & Item \\
\hline General & General data & $1-5$ \\
background & Details of the contribution made (job, internship, scholarship...) & $6-8$ \\
information & Degree of contribution to SDGs & $9-26$ \\
\hline Competencies & Degree of development of transversal competencies & $27-33$ \\
and Learning & Degree of development of transversal competencies for sustain- & $34-43$ \\
Outcomes for & ability & $44-81$ \\
Sustainability & Degree of development of learning outcomes for sustainability & \\
\hline
\end{tabular}

Both questionnaires include closed items and short questions to avoid them being too time-consuming or confusing (Alaminos \& Castejón, 2006; Palou, 2011). The questions were formulated taking into account the following aspects: 1) clarity, precision and comprehensibility; 2) reference to one aspect or topic; 3 ) simple, direct language that is appropriate to the university population; 4) avoiding repeated or insufficiently separated questions; 5) avoiding negative formulations, and 6) avoiding questions that might be uncomfortable, threatening or judgmental.

With regard to the order of the items, they start with identification in order to gain the concentration of the respondent. Then they follow the "funnel" procedure, going from more general to more specific items. The questions are written as propositions that express positive ideas, to be rated in a 5-point Likert scale (from $1=$ very low to 5 = very high). In this kind of scale, the response is coded on the basis of a numerical scale that obliges the person to rate each item more favorably or unfavorably (Alaminos \& Castejón, 2006; Albert, 2007).

\section{Participants}

Analysis of the validity of the content of the questionnaires was conducted by 10 experts (see Table 2). 


\section{Table 2}

Profile of the People Validating the Content of the Questionnaires

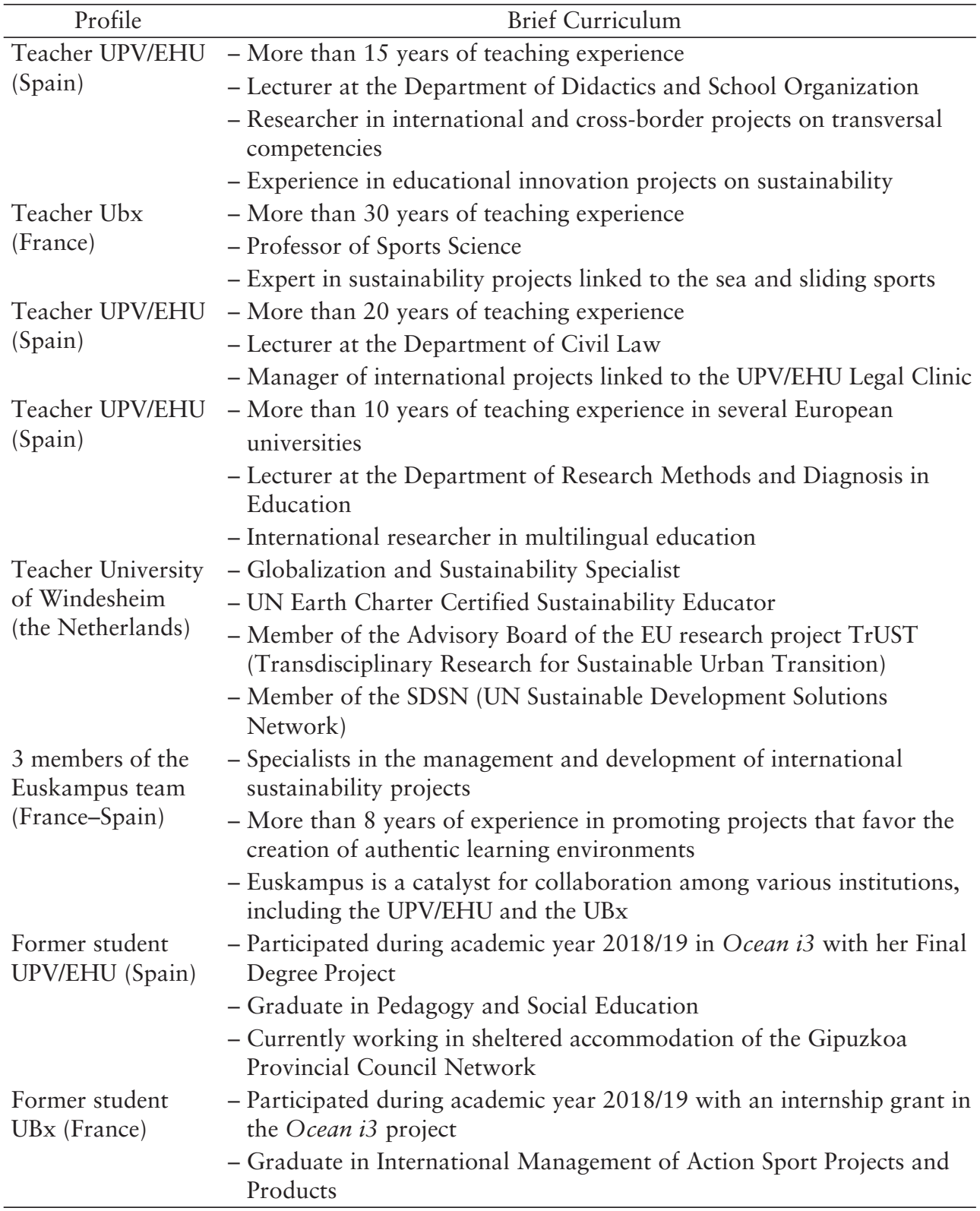

The distribution of the participants across the different phases of the project was as follows:

Phase I. Research team.

Phase II. An expert from the UPV/EHU in skills and sustainability. 
Phase III. 9 people: 4 teachers, 2 former students, 3 members of Euskampus.

Phase IV. The entire study population: 37 students and 33 lecturers from the UPV/ EHU and the Ubx. UPV/EHU students: 21 females and 5 males, UBx students: 8 females and 3 males, UPV/EHU teaching staff: 14 women and 8 men, and UBx teaching staff: 7 women and 4 men.

The process of preparation and validation of the questionnaires followed the recommendations made by CEISH, the UPV/EHU committee for ethics in research using human beings and the good practices recommended by the relevant literature (González, 2002; Parrilla, 2009). Therefore, the participants were asked for their prior, informed consent by signing voluntarily, and their anonymity and privacy were ensured at all times.

\section{Results}

\section{Validation by Judges: Validity of Content}

"Validity of content" means how far the process of going from theoretical to empirical measures the concept in question (Ruiz, 2014) and it is essential to make inferences and generalizations on the basis of the results obtained. As Ruiz (2014) states, "With validity of content the aim is to determine how far the items in a tool are representative of the domain or universe of content of the property to be assessed" (p. 75).

For these questionnaires, an analysis of items was conducted, consisting of assessment of the contents by a group of experts in the area in question (validation by judges), who took the following indicators into account: a) unequivocally, which means whether the item is clear and should be kept or causes confusion and should be deleted; b) pertinence, i.e., whether or not it measures what it aims to measure, on the basis of which it should be kept or removed; c) the importance or bearing of the item on the object of study, and d) any suggestions/comments they might wish to make. Their assessments are summarized in Table 3.

\section{Table 3}

Assessments by the People Validating the Content of the Questionnaires (Phase III)

\begin{tabular}{|c|c|}
\hline Judges & Summarized valuations \\
\hline $\begin{array}{l}\text { Teacher UPV/EHU } \\
\text { (Spanish version) }\end{array}$ & $\begin{array}{l}\text { - Working session on the proposed modifications to the initial draft of } \\
\text { the IraunIK and IraunIR questionnaires }\end{array}$ \\
\hline $\begin{array}{l}\text { Teacher UBx } \\
\text { (French version) }\end{array}$ & $\begin{array}{l}\text { - After each set of questions, leave an open item for comments or con- } \\
\text { tributions }\end{array}$ \\
\hline $\begin{array}{l}\text { Teacher UPV/EHU } \\
\text { (Spanish and } \\
\text { Basque version) }\end{array}$ & $\begin{array}{l}\text { - It is proposed to incorporate an item relating to: 1) ability to respond } \\
\text { to situations of uncertainty; 2) tolerance; and 3) use of ICTs }\end{array}$ \\
\hline $\begin{array}{l}\text { Teacher UPV/EHU } \\
\text { (English version) }\end{array}$ & $\begin{array}{l}\text { - More clarity on items: } 11.29 \\
\text { - Syntax corrections: } 9.17 / 10.2 / 11.25 / 11.36 / 11.37\end{array}$ \\
\hline $\begin{array}{l}\text { Teacher University } \\
\text { of Windesheim } \\
\text { (the Netherlands) } \\
\text { (Spanish version) }\end{array}$ & $\begin{array}{l}\text { - Explain, at least briefly, the essence of the transversal competencies in } \\
\text { the context of Ocean i3 }\end{array}$ \\
\hline
\end{tabular}


Continuation of Table 3

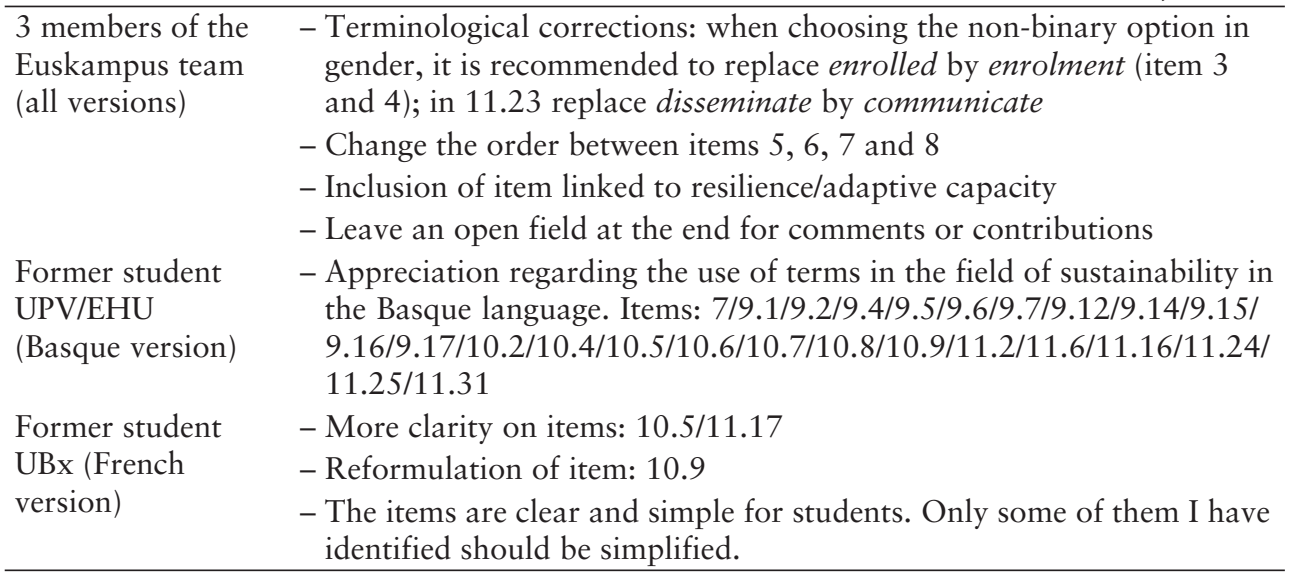

The experts suggested adding some open items to the questionnaire (e.g., Would you include any other competency that is not mentioned above? Which one? Would you include any learning outcome that is not mentioned above? Which one?) in order to gather information of a qualitative nature that might amplify and qualify the closed items. However, the scant information provided by the responses to these open questions did not give enough evidence to consider them relevant, pertinent items to include in the questionnaires.

Finally, it is worth pointing out that these experts were able to choose the language in which to assess the questionnaires as they had been translated into the four languages used in the project, and therefore the content and the form of the items were assessed in all their different language versions.

\section{Pilot Trial: Reliability}

The preliminary questionnaires (II) resulting from phase IV of the study were subjected to a process of empirical validation to test their reliability. This focused on establishing how far a specific procedure for turning a concept into a variable gave the same results repeated with the same or similar techniques (Ruiz, 2014). This test is considered essential in preparing a tool (Gaitán \& Piñuel, 1998), and the pilot test was run with these aims (Phase V):

1) to test the reliability of each questionnaire;

2) to make sure that the target audience of each questionnaire properly understands the different items put in formal terms;

3) to find out whether the response time is reasonable;

4) to find out how interesting students and lecturers find the questionnaire;

5) to analyze whether the items formulated fulfil the purpose for which they were intended.

The reliability of the questionnaire was assessed based on the statistical package SPSS 26 (Statistical Package for the Social Sciences), using the two most widely-used procedures in social research (Cea, 2001): the Cronbach alpha coefficient and the Split Half Method. 
The Cronbach alpha coefficient establishes the internal consistency of the items by calculating the covariance between them (Celina \& Campo, 2005; Marín-Martínez \& Reidl-Martínez, 2013) and makes it possible to assess how far the reliability of the test would be improved (or worsened) if a particular item were removed (RodríguezRodríguez \& Reguant-Álvarez, 2020). This analysis was applied to 4 of the 6 subsections of the questionnaires, which included 73 items concerning participants' perception of the competencies and learning outcomes achieved. The sub-sections concerning the general and contextual data types were excluded. The IraunIK questionnaire scored a coefficient of 0.974 and the IraunIR questionnaire scored a coefficient of 0.984. As Fox (1987) states, in estimating responses, correlations of over 0.700 or even 0.600 are acceptable in the case of estimates of option or criticism, as in the case of perception in this survey. Therefore, considering a range of 0.600 to be acceptable, it can be stated that the IraunIK and IraunIR questionnaires are highly reliable, as the contribution of each item to its respective scale (corrected homogeneity index, which gives the capacity for discrimination) is in all cases positive ranging from 0.973 to 0.975 in IraunIK and from 0.983 to 0.984 in IraunIR if the item is removed.

The Split Half Method was then applied. This serves to check the "internal consistency" of a measurement and is more important when applied to multiple items to check whether or not they converge in the configuration of a single section (Cea, 2001). As with the above procedure, 4 sub-sections were analyzed, excluding the 2 concerning general and contextual data.

The IraunIK questionnaire gained a result of 0.989 for the Spearman Brown coefficient; the Cronbach alpha for the first half, made up of 37 items (odd-numbered), was 0.954 and 0.942 for the second half, made up of the other 36 items (even-numbered).

The IraunIR questionnaire scored a Spearman Brown coefficient of 0.989. The Cronbach Alpha coefficient for the first half (made up of 37 odd-numbered items) was 0.969 and for the other half -0.966 (made up of 36 even-numbered items).

While the values resulting from the Split Half Method are slightly lower than those gained in the previous reliability analysis, they are above 0.9 , so it can be stated that the reliability index is high, according to the values given by Fox (1987).

To sum up, the results of the application of the pilot test has helped improve both questionnaires. Thus, the importance of this analysis does not lie in the results given by the students and lecturers participating, but in the technical value of the questionnaire itself, allowing it to be improved and perfected. The value of this analysis can be said to lie in conducting the reliability test and rethinking items in the sub-sections of the questionnaire according to the results obtained. Hence, when the results of the pilot test were analyzed, certain areas for improvement were found which made the final version more agile and helped make it more understandable in both formal and conceptual terms.

\section{Final Preparation of the Questionnaires}

The result of this process is preparation of the final version of the IraunIK and IraunIR questionnaires. In the appendix, only the full IraunIK questionnaire addressed to students is included, because IraunIR addressed to teachers is practically identical to the one attached. Note that in both cases, the reference to the Ocean i3 learning for sustainability environment (Sub-sections 1 and 2) may be replaced by the specific naming of another learning environment, context or project, as this reference is circumstantial to the purpose of placing the respondents. 


\section{Conclusions}

The data presented has shown that both the questionnaire aimed at students learning for sustainability environments (IraunIK) and the questionnaire aimed at lecturers (IraunIR) make it possible to find out how the participants perceive the competencies and the learning outcomes involved in terms of sustainability.

The phases undertaken in the process of validating the questionnaires by subjecting them to review and judgement by exerts have led to greater clarity in the formulation of the items in these questionnaires, as well as improvements in the way the items are expressed in the languages in which they were produced. They have also made the sections studied more understandable.

Throughout this process, judgement by experts has ensured the validity of the questionnaire, by deciding that the items in it are representative of the universe of content being measured.

The questionnaires used in the pilot test have shown that they are accessible to the population at which they are aimed, and submitting them to the Cronbach alpha and Split Half Method tests led to the conclusion that they are reliable measuring tools.

After analyzing the processes to validate the content and reliability of the questionnaires, it has been concluded that the IraunIK questionnaire for students and the IraunIR questionnaire for lecturers can be used to determine students' and lecturers' perception of the learning outcomes for students participating in learning for sustainability environments in higher education. In terms of validity and reliability of the results, it can be concluded that they could be transferred to other sustainability learning environments.

These questionnaires can serve, not only to identify students' and lecturers' perception of learning outcomes, but can themselves identify competencies and learning outcomes linked to ESD. Thus, they can help design and plan other educational actions to be carried out in higher education for the development of competencies for sustainability.

Taking into account that one of the difficulties faced by teachers in ESD is the monitoring of the competencies to be developed by their students, this paper offers a proposal of learning outcomes that teachers can use to guide their system of work and later assessment (see appendix).

In short, the items in the questionnaire refer to sustainable development competencies and they are not linked to a specific area of knowledge, neither to a territorial university context. Therefore, these items are related to competencies to be developed in any learning process on sustainability in higher education.

\section{References}

Alaminos, A., \& Castejón, J. L. (2006). Elaboración, análisis e interpretación de encuestas, cuestionarios y escalas de opinión [Preparation, analysis and interpretation of surveys, questionnaires and opinion scales]. Marfil.

Albert, M. J. (2007). La investigación educativa. Claves teóricas [Educational research. Theoretical keys]. McGraw Hill.

Barth, M., Godemann, J., Rieckmann, M., \& Stoltenberg, U. (2007). Developing key competencies for sustainable development in higher education. International Journal of Sustainability in Higher Education, 8(4), 416-430. 
Bradbury-Huang, H. (2010). What is good action research? Why the resurgent interest? Action Research Journal, 8(1), 93-109.

Care, E., \& Luo, R. (2016). Assessment of transversal competencies. Policy and practice in the Asia-Pacific region. UNESCO. https://neqmap.bangkok.unesco.org/wpcontent/uploads/2019/09/246590eng.pdf

Cea, M. A. (2001). Metodología cuantitativa: estrategias y técnicas de investigación social [Quantitative methodology: Strategies and techniques of social research]. Síntesis.

Celina, H., \& Campo, A. (2005). Aproximación al uso del coeficiente Alfa de Cronbach [Approach to the use of Cronbach's Alpha coefficient]. Revista Colombiana de Psiquiatría [Colombian Journal of Psychiatry], 34, 572-580.

Coghlan, D. (2007). Insider action research: Opportunities and challenges. Management Research News, 30(5), 335-343. https://doi.org/10.1108/01409170710746337

CRUE. (2012). Directrices para la introducción de la Sostenibilidad en el Curriculum. Documento aprobado por el Comité Ejecutivo del Grupo de Trabajo de Calidad Ambiental y Desarrollo Sostenible de la CRUE, celebrado en Valladolid el 18 de abril de 2005, revisado y actualizado en marzo de 2011 [Guidelines for the introduction of sustainability in the curriculum. Document approved by the Executive Committee of the CRUE Working Group on Environmental Quality and Sustainable Development, held in Valladolid on 18 April 2005, revised and updated in March 2011]. https://www.crue.org/Documentos\%20compartidos/Declaraciones/Directrices_ Sostenibli-dad_Crue2012.pd

CRUE. (2019). Manifiesto de CRUE Universidades Españolas por un planeta más sostenible [Manifesto of CRUE Spanish Universities for a more sustainable planet]. https://www.crue.org/2019/12/manifiesto-de-crue-universidades-espanolas-por-unplaneta-mas-sostenible-diciembre-2019/

Fox, D. J. (1987). El proceso de investigación en educación [The research process in education]. EUNSA.

Gaitán, J. A., \& Pińuel, J. L. (1998). Técnicas de investigación en comunicación social. Elaboración y registro de datos [Research techniques in social communication. Data processing and recording]. Síntesis.

Goddard, J., Kempton, L., \& Vallance, P. (2012). The civic university: Connecting the global and the local. In R. Capello, A. Olechnick, \& G. Gorzelak (Eds.), Universities, cities and regions: Loci for knowledge and innovation creation (pp. 43-63). Routledge.

González, M. (2002). Aspectos éticos de la investigación educativa [Ethical aspects of educational research]. Revista Iberoamericana de educación [Iberoamerican Journal of Education], 29, 85-103.

Haan, G. de. (2010). The development of ESD-related competencies in supportive institutional frameworks. International Review of Education, 56, 315-328.

Lahneman, W. (2010). The need for a new intelligence paradigm. International Journal of Intelligence and Contraintelligence, 23(2), 201-225.

Leal Filho, W., Pallant, E., Enete, A., Richter, B., \& Brandli, L. L. (2018). Planning and implementing sustainability in higher education institutions: An overview of the difficulties and potentials. International Journal of Sustainability in Development \& World Ecology, 25, 713-721. 
Marín-Martínez, A., \& Reidl-Martínez, L. M. (2013). Validación psicométrica del cuestionario - Así nos llevamos en la escuela - para evaluar el hostigamiento escolar (bullying) en primarias [Psychometric validation of the questionnaire - This is how we get along at school - to assess bullying in primary schools]. Revista Mexicana de Investigación Educativa [Mexican Journal of Educational Research], XVIII(56), 11-36.

Martínez, M. P., Aznar, P., Ull, A., \& Piñero, A. (2007). Promoción de la sostenibilidad en los currícula de la enseńanza superiro desde el punto de vista del profesorado: un modelo de formación por competencias [Promoting sustainability in higher education curricula from the teacher's point of view: A competency-based training model]. Educación Siglo XXI [21 ${ }^{\text {st }}$ Century Education], 25, 187-208.

Mawonde, A., \& Togo, M. (2019). Implementation of SDGs at the university of South Africa. International Journal of Sustainability in Higher Education, 20, 932-950.

Mazzucato, M. (2018). Mission-oriented research \& innovation in the European Union. A problem-solving approach to fuel innovation-led growth. European Union. https://ec.europa.eu/info/sites/info/files/mazzucato_report_2018.pdf

McNiff, J., \& Whitehead, J. (2011). All you need to know about action research (2 $\left.2^{\text {nd }} \mathrm{ed}.\right)$. Sage Publications.

Mori, R., Fien, J., \& Horne, R. (2019). Implementing the UN SDGs in Universities: Challenges, opportunities, and lessons learned. Sustainability, 12, 129-133.

Murga-Menoyo, M. A. (2015). Competencias para el desarrollo sostenible: las capacidades, actitudes y valores meta de la educación en el marco de la agenda global post-2015 [Competencies for sustainable development: Target skills, attitudes and values for education in the framework of the post-2015 global agenda]. Foro de Educación [Educational Forum], 13(19), 55-83. doi: http://dx.doi.org/10.14516/fde.2015.013.019.004

Murillo-Vargas, G., Hernan, C., \& Ico, D. (2020). Mapping the integration of the sustainable development goals in Universities: Is it a field of study? Journal of Teacher Education for Sustainability, 22(2), 7-25. doi: 10.2478/jtes-2020-0013

OECD. (2019). El trabajo de la OCDE sobre educación y competencias [The OECD's work on education and competencies]. https://www.oecd.org/education/El-trabajode-la-ocde-sobre-educacion-y-competencias.pdf

UN (United Nations). (2015). Asamblea General. Transformar nuestro mundo: La Agenda 2030 para el Desarrollo Sostenible [General meeting. Transforming our world: The 2030 Agenda for Sustainable Development], A/RES/70/1. https:/unctad.org/ system/files/official-document/ares70d1_es.pdf

Paletta, A., \& Bonoli, A. (2019). Governing the university in the perspective of the United Nations 2030 Agenda: The case of the University of Bologna. International Journal of Sustainability in Higher Education, 20, 500-514.

Palou, B. (2011). Análisis de los elementos configurativos de la ciudadanía como condición para la integración de la juventud de origen magrebí en Cataluńa [Analysis of the configurative elements of citizenship as a condition for the integration of young people of Maghrebi origin in Catalonia]. Revista de Investigación Educativa [Journal of Educational Research], 30(1), 181-195.

Parrilla, A. (2009). ¿Y si la investigación sobre inclusión no fuera inclusiva? Apuntes desde una investigación biográfico-narrativa [What if research on inclusion was not inclusive? Notes from a biographical-narrative research]. Revista de Educación [Journal of Education], 343, 101-117. 
Ponsa, F. (2016). Ensanchando el pensamiento: La comunidad ampliada de inteligencia [Broadening thinking: The wider intelligence community]. Notes Internacionals CIDOB, 164, 1-4.

Prabawani, B., Hadi, S. P., Zen, I. S., Afrizal, T., \& Purbawati, D. (2020). Education for sustainable development as diffusion of innovation of secondary school students. Journal of Teacher Education for Sustainability, 22(1), 84-97.

Rieckmann, M. (2011). Key competencies for a sustainable development of the world society. Results of a Delphi study in Europe and Latin America. GAIA, 20(1), 48-56.

Rieckmann, M. (2012). Future-oriented higher education: Which key competencies should be fostered through university teaching and learning? Futures, 44, 127-135.

Rodríguez-Rodríguez, J., \& Reguant-Álvarez, M. (2020). Calcular la fiabilidad de un cuestionario o escala mediante el SPSS: El coeficiente alfa de Cronbach [Calculating the reliability of a questionnaire or scale using the SPSS: Cronbach's alpha coefficient]. REIRE Revista d'Innovació $i$ Recerca en Educació [Journal of Innovation and Research in Education], 13(2), 1-13. https://doi.org/10.1344/reire2020.13. 230048

Ruiz, A. (2014). La operacionalización de elementos teóricos al proceso de medida [Operationalisation of theoretical elements to the measurement process]. http://hdl.handle.net/2445/53152

Sachs, J. D., Schmidt-Traub, G., Mazzucato, M., Messner, D., Nakicenovic, N., \& Rockström, J. (2019). Six transformations to achieve the Sustainable Development Goals. Nature Sustainability, 2(9), 805-814.

Sáez de Cámara, E., Fernández, I., \& Castillo-Eguskitza, N. (2021). A holistic approach to integrate and evaluate sustainable development in higher education. The case study of the University of the Basque Country. Sustainability, 13(1), 392. https://doi.org/10.3390/su13010392

Salite, I., Fjodorova, I., \& Ivanova, O. (2020). Does the JTES help us create deeper personal meanings for sustainable education? Journal of Teacher Education for Sustainability, 22(2), 1-6. doi: 10.2478/jtes-2020-0012

Stefanova, V., \& Leopold, T. (2018). Cinco cosas que debe saber acerca del futuro de los puestos de trabajo [Five things you need to know about the future of jobs]. World Economic Forum. https://es.weforum.org/agenda/2018/10/cinco-cosas-quedebe-saber-acerca-del-futuro-de-los-puestos-de-trabajo/

University of the Basque Country. (2018). Plan Estratégico de la UPV/EHU 2018 2021. [UPV/EHU Strategic Plan 2018-2021]. https://www.ehu.eus/es/web/ idazkaritza-nagusia/upv-ehuren-plan-estrategikoa-2018-2021 (accessed on 17 February 2021).

University of the Basque Country. (2019). EHU agenda for sustainable development. https://www.ehu.eus/documents/4736101/11938005/EHUAgenda-2030-ENG.pdf/ 487b2c83-51e1-d0e2-dcd1-af419b2b5c26

Uranga, M. J., Cruz, E., Eizagirre, A., Gil, P., Losada, D., \& Ruiz de Gauna, P. (2019). Catálogo de competencias transversales de la UPV/EHU [Catalogue of transversal competences of the UPV/EHU]. Servicio editorial de la UPV/EHU [UPV/EHU Publishing Service.]. 
Correspondence concerning this article should be addressed to Itziar RekaldeRodríguez, Lecturer, Department of Didactics and School Organization, Faculty of Education, Philosophy and Anthropology, University of the Basque Country, Tolosa Avenue, 70, 20018, Donostia-San Sebastián, Spain. Email: itziar.rekalde@ehu.eus

\section{Appendix 1}

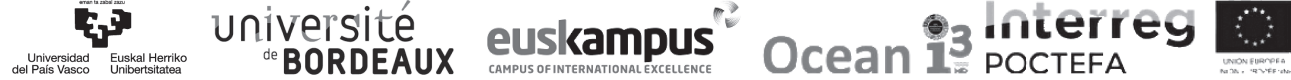

\section{IraunIK Questionnaire to Assess Transversal Competencies for Sustainability}

This questionnaire aims at identifying the competencies and learning outcomes developed by students taking part in the Campus Euskampus-Bordeaux cross-border project "Ocean i3".

It is made up of three sections:

- General details to be able to contextualize the information you give in your responses.

- Questions about your contribution to the project and to the Sustainable Development Goals (SDGs).

- Questions about your perception of how far you have developed competencies and learning outcomes for sustainability by taking part in this project. You will need about 20 minutes to complete the questionnaire. basis.

The questionnaire is anonymous and the data will be processed on a confidential

Thank you for your cooperation.

1. Gender (choose one):

o Male

o Female

o Non-binary

2. Age (choose an age range)

3. Bachelor's/postgraduate/Master's course (specify):

4. School or faculty in which you are enrolled (specify):

5. Home university:

o UPV/EHU University of the Basque Country

o UBx Université de Bordeaux

6. Languages you have used to take part in Ocean i3 (you can choose more than one):
o Basque
o Spanish
o French
o English
o Other (specify):

7. Key words of your task/activity (graduate paper, internship, etc.): 
8. Area of impact of your task/activity (you can choose more than one):
o Academic
o Social
o Educational
o Cultural
o Environmental
o Business
o Other (please specify):

9. State to what extent you feel your work/activity has contributed to the Sustainable Development Goals (SDGs) listed below, where $1=$ very low and $5=$ very high

9.1. No poverty

9.2. Zero hunger

9.3. Good health and well-being

9.4. Quality education

9.5. Gender equality

9.6. Clean water and sanitation

9.7. Affordable and clean energy

9.8. Decent work and economic growth

9.9. Industry, innovation and infrastructure

9.10. Reduced inequalities

9.11. Sustainable cities and communities

9.12. Responsible consumption and production

9.13. Climate action

9.14. Life below water

9.15. Life on land

9.16. Peace, justice and strong institutions

9.17. Partnerships for the goals

9.18. Linguistic and cultural diversity

10. State to what extent you feel your participation in the learning environment/ experiment/project has helped develop the transversal competencies listed below, where $1=$ very low and $5=$ very high

10.1. Autonomy and Self-Regulation

10.2. Social Commitment

10.3. Professional Responsibility and Ethics

10.4. Information Management and Digital Citizenship

10.5. Innovation and Enterprise

10.6. Critical Thought

10.7. Teamwork 
11. State to what extent you feel your participation in the learning environment/ experiment/project has helped develop the competencies listed below, where $1=$ very low and 5 = very high

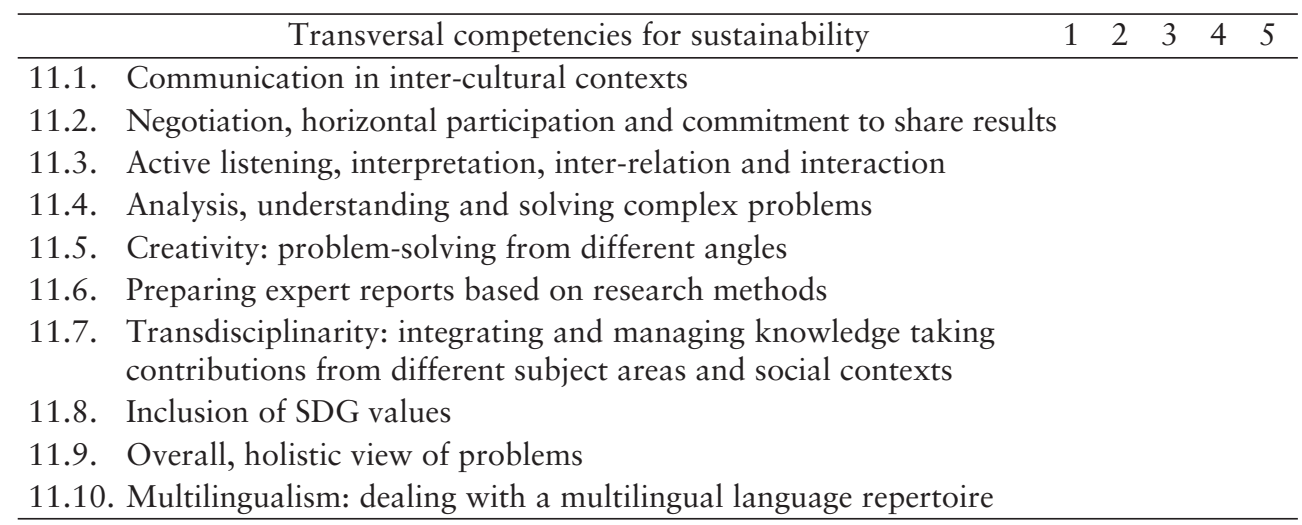

12. State to what extent you feel your participation in the learning environment/ experiment/project has helped achieve the learning outcomes listed below, where $1=$ very low and $5=$ very high

$\frac{\text { Learning outcomes for sustainability }}{\text { 12.1. } \quad \text { Relating knowledge from different academic fields or subjects to }}$ identify problems and their possible solutions using a sustainable approach.

12.2. Discussing the implications of specific policies, programs or practices to pursue the SDGs at the individual, social, cultural, environmental and/or global level.

12.3. Identifying opportunities and challenges for more sustainable development when planning measures linked to a specific context or area of study.

12.4. Identifying the needs of the economic and employment context, valuing dignity at work and setting an order of priority to favor employability.

12.5. Proposing actions, interventions and improvements, either individual or collective, which take into account the SDGs.

12.6. Anticipating the impact of personal, local and national decisions or activities on other people and regions in the world.

12.7. Interpreting the information gathered from different sources, assessing their appropriateness and social, linguistic and cultural scope from a critical perspective.

12.8. Analyzing the environmental impact of proposed scientific and technical solutions/actions/improvements, assessing their practicality and appropriateness according to criteria of sustainability and social justice.

12.9. Analyzing the social impact of proposed scientific and technical solutions/actions/improvements, assessing their practicality and appropriateness according to criteria of sustainability and social justice. 
Continuation of Table

12.10. Reflecting on how individual lifestyle decisions influence social, economic and environmental development in their immediate surroundings.

12.11. Identifying the process to follow in order to implement an innovative solution to a problem related to people's quality of life.

12.12. Using the right research method to define sustainable goals in work planned.

12.13. Using the right research method to find transformational, environment-friendly solutions.

12.14. Working proactively to design and implement an action/initiative/ research to meet a social need within the Ocean i3 framework.

12.15. Proposing innovative solutions to problems related to healthy consumption habits.

12.16. Managing available resources sustainably in accordance with healthy consumption habits.

12.17. Formulating interdisciplinary proposals to meet challenges related to sustainable human development.

12.18. Coming up with and assessing sustainability-driven ideas for innovation and enterprise.

12.19. Showing others human beings' impact on the oceans and the importance of healthy, clean oceans.

12.20. Showing respect and empathy towards any cultural differences arising from the communicative interaction within Ocean i3.

12.21. Collaborating with other people to design and implement initiatives to meet a social need within the framework of Ocean i3.

12.22. Active listening in work groups made up of people from diverse social, cultural and academic backgrounds.

12.23. Interacting with people from different backgrounds and areas (academic and social) in a transdisciplinary way to construct academic knowledge generated within the framework of Ocean i3.

12.24. Disseminating the scientific knowledge generated in a transdisciplinary way in academic forums, networks and spaces.

12.25. Raising other people's awareness so that that they can achieve a change in their behavior and attitudes towards sustainability.

12.26. Expressing ideas and arguments correctly in the different languages used in the Ocean i3 community.

12.27. Using a technical/academic language appropriate to your course, including terms and concepts related to sustainable development.

12.28. Expressing ideas using verbal and non-verbal communication appropriate to the cultural context of the work group within the Ocean i3 community.

12.29. Using positive, non-sexist language to avoid falling into cultural stereotypes and prejudices.

12.30. Preparing academic documents based on research methods using different languages, in line with the established formal and content criteria. 
Continuation of Table

12.31. Reflecting on how responsibly you have acted in performing the tasks to which you are committed to meet a challenge proposed by a social stakeholder within the framework of Ocean i3.

12.32. Assessing the ethical consequences arising from the decisions taken in a situation.

12.33. Showing respect in different academic and professional contexts without discriminating on socio-cultural or gender grounds.

12.34. Questioning the social and environmental situation by considering the principles, facts, attitudes and values involved in it to decide on one's own position.

12.35. Making a positive change to one's own actions as a result of comparison with the experiences and learnings of others.

12.36. Being aware of the link between decisions taken and the SDG values driven by them.

12.37. Feeling responsible for environmental and social impacts of one's own lifestyle.

12.38. Being able to identify with the SDGs. 